\title{
Editorial: Reconfiguring Foundational Pedagogies through Theoretical Frameworks
}

\section{James Garraway \\ Vivienne Bozalek}

Throughout the years there have been regular national and regional colloquia on foundation provision teaching, learning and curriculum development, in order to promote scholarship in the field and also to get those teaching in foundation provision together to enhance a collective awareness and solidarity. In 2015, based on such regional and national colloquia, and subsequent writing for publication retreats, there was a special edition of the South African Journal of Higher Education (SAJHE 2015, 29:1). Dhunpath's and Vithal's 2012 book on Alternative Access to Higher Education: Underprepared Students or Underprepared Institutions?, which was published some years prior to this special issue, focused attention on the nature and success of foundation provision. Though there has been some theorisation of teaching and learning in these and other volumes, this has often been quite restricted to debates around, for example, 'active learning', 'literacies' and 'epistemological access'. Although these have proven to be useful lenses through which to understand teaching and learning, they have also tended to be under-theorised. Thus the purpose of this volume is to encourage the emergence of and discussion of theorisations of teaching and learning in foundation provision, including more recent ones, which can expand on and influence our understandings.

Teaching and learning initiatives in foundation provision have the potential to improve teaching practices more generally across the university ${ }^{1}$.

${ }^{1}$ Foundation studies include all forms of curriculum extension/ enrichment which fall under this term constructed by the Department of Higher Education and Training. 
The innovative practices and imaginative teaching approaches which are used in these programmes in order to engage with students in transition into higher education are, however, not always underpinned by deeper theoretical understandings about how knowledge is structured, how pedagogies are enacted and how new ideas come to be understood and developed. Such understandings matter as they inform, support and strengthen the teaching initiatives, and can be used to further engage with others attempting similar initiatives. Theory, in some instances, enables practices to be lifted from their contexts so that they are more easily transferable to different subjects or levels, and, in other circumstances, to alert higher education teachers to the importance of including epistemology, ontology and ethics in their thinking. As Kurt Lewin's ([1943/1951] 2003) maxim reminds us: 'There is nothing more practical than a good theory'.

Where theorisations of foundation practices have occurred in the literature, there has often been much focus on active, constructivist approaches but these have themselves been under theorised. More recently there has been some shift to Margaret Archer's social realism theorisations and other realist theories such as activity and legitimation code theory. Social justice theories and legitimate participation of students, drawing on the work of Nancy Fraser, were furthermore highlighted at the 2016 HELTASA conference, and have provided for a new and timely way to view theory or practices. There are many more emerging theorisations, for example from feminist new materialist and post humanist writers, that have opened up new spaces for enriching our understanding of teaching and learning.

This special edition of Alternation seeks to provide a platform for these fresh theorisations of teaching and learning in foundation provision, and thus also in higher education more generally. In so doing it is hoped that readers may gain insights into improvements for the benefit of their students.

The opening article of the volume by James Garraway and Vivienne Bozalek, is titled, 'Theoretical Frameworks and the Extended Curriculum Programme'. It provides an overview of what has been written on Foundation Provision, or extended curriculum programmes, particularly by looking at recent special issues of books/ booklets and journals. The article uses examples from current writings to exemplify epistemic access and academic literacy approaches to teaching and learning, and theorisations such as legitimation code theory, social realism, activity theory and constructivism. It then calls for more varied theorisations and, where this has occurred, invites readers to 
engage with recent and fresh theorisations such as those in the posthumanist tradition.

Many of the papers in this special issue make reference to or grapple with the consequences for foundation provision of 2015 - 2017 \# student protests, which swept across South African universities, using different theoretical lenses in their analyses of these events. There are four articles specifically focused on this matter, or which engage aspects of the matter, as follows.

Kathy Luckett's article refers to Mignolo's term 'epistemic decolonisation' by which she means the contradictions of modernity and coloniality which Black students experience in extended curriculum programmes (ECPs) located at historically white higher education institutions. In her 'A Critical Self-reflection on Theorising Education Development as 'Epistemological Access' to 'Powerful Knowledge', she argues that separate ECPs are no longer tenable in tertiary education, after the protests. Theoretically, she considers the work of Basil Bernstein, in particular the concepts of 'epistemological access' and 'powerful knowledge' which have their roots in Bernsteinian theory, and speculates on what a decolonial critique of these concepts would be. She uses these insights to re-imagine the undergraduate curriculum for South African higher education and other postcolonial contexts.

The second paper, 'Just(ice) Do It! Re-membering the Past through coAffective Aesthetic Encounters with Art/ History' by Nike Romano, refers to the student protests, with an attempt to decolonise the Design of ECP. She proposes critical arts-based pedagogical encounters founded in theoretical approaches of critical posthumanism and feminist new materialism to offer possibilities for affecting both the students' and the teacher's becoming, in the higher education classroom. She draws on the work of feminist philosophers and theorists, Karen Barad, Donna Haraway and Bracha Ettinger, which she reads diffractively through one another to come to new understandings of subjectivity as co-affecting and co-emerging in the art history ECP curriculum. Romano uses a case study of a lesson based on the removal of the Rhodes statue at the University of Cape Town, which was diffracted through two additional artworks - the ancient Greek sculpture Winged Nike or the Victory of Samothrace, and the artist Sethembile Msezane's performance, entitled, Chapungu - the day Rhodes fell -, which she performed when the statue was removed. She draws on students' situated knowledges in relation to the lesson, 
considering the ethico-onto-epistemological effects of the lesson on the students and herself.

The third paper which refers to the aftermath of the student protests and fallist movements is that by Aditi Hunma, Moeain Arend, Gideon Nomdo, Catherine Hutchings, and Sean Samson, and is titled 'Revisiting Writer Identities in Discomforting Spaces: The Envisioned Self in Writing'. The article is an attempt to re-envision writer identities in turbulent times in South African higher education, as a consequence of the fallist movement. They make use of Zembylas and Boler's notion of a pedagogy of discomfort, which destabilises the notion of a coherent self by using texts and concepts which help to defamiliarise taken-for-granted views, using the tool of reflexive writing. Their paper refers to a Humanities ECP course on foundational academic literacy, where they see their central function as ECP teachers to provide students with spaces where they can experience a sense of belonging, at the same time as providing epistemological access to disciplines.

The fourth paper, Corinne Knowles's 'Access or Set Up? A Critical Race, Feminist, Black Consciousness, and African Feminist perspective on Foundation Studies in South Africa' directly addresses the student protests, and the ongoing concerns of gender, race and class inequalities to which these movements alerted the higher education community. Knowles uses Critical Race and African Feminism and Black Consciousness as theoretical lenses to consider notions such as 'success' in Foundation Provision, and to understand needed transformation in universities around race, class and gender. The poor, black student is placed at the centre rather than the periphery of the university, the focus of which should be the public good, as well as the mind, body and spirit of such students.

Like Romano, Delphi Carstens, in his article 'New Materialist Perspectives for Pedagogies in Times of Movement, Crisis and Change', proposes new materialist perspectives as useful to ECP pedagogies. He shows the reader how new materialist theories enable us to rethink ECP teaching practices in entangled ethical, epistemological and ontological ways to make teaching more alive for students. His article also outlines the current crisis of life facing the earth in the form of the Anthropocene or Capitalocene, where the human and other biological life is threatened with extinction. These are the sorts of issues he brings to the attention of the ECP students in his classroom. His contribution also usefully outlines four major topoi or principles which inform new materialist pedagogies in the ECP - one, that materialities are 
important and should be given attention, rather than just linguistic or the cultural aspects of existence; two that education needs to pay more attention to what is happening in the life sciences; three, that matter has some form of agency; and four, that entities do not precede their relations but rather emerge from them. Carstens sees these as important issues both for ECP students to engage with and to inform the pedagogical practices of the ECP teacher.

With her article, 'Disruption by Curriculum Design: Using Steve Biko's I Write What I Like as a Tool for Participatory Parity in post-Apartheid Higher Education', Shannon Morreira continues the topic of decolonisation, but now from a different perspective. Morreira draws on resources from legitimation code theory (LCT) to focus attention on issues of decolonisation in the curriculum in the social sciences. The author poses the important curriculum design question of: 'Is it (curriculum design) 'transformation' and 'decolonisation' of our curricula to improve parity of participation; or is it 'schooling'/ 'disciplining' students into the university environment so that they succeed on the university's terms? Is it possible to do both?' This remains an important question and balancing act for all those involved in foundation curriculum design.

The article by Honjiswa Conana, Delia Marshall, and Deon Solomons, 'Supporting Student Learning in Foundation Programmes and Beyond: Using Legitimation Code Theory as a Theoretical Lens to Think about Transition', further introduces the reader to legitimation code theory as a lens to examine teaching Physics in the extended curriculum. The article alerts the reader to representational tools necessary for understanding and working with Physics discourse. The LCT tools allow for the plotting of 'semantic profiles' that characterize the movement between the concrete and the abstract, as well as the use of semantically dense representations in the pedagogical practices of this physics course and in students' approaches to problem tasks. This type of theorisation can alert teachers to what kind of knowledge they are presenting to students, and in what form.

As with Conana and Marshall, Ellery also draws on LCT to examine pedagogy in foundation science provisions. In her 'Congruence in Knowledge and Knower Codes: The Challenge of Enabling Learner Autonomy in a Science Foundation Course' Karen Ellery draws on LCT's knowledge and knower codes to analyse congruence of the foundation courses with more mainstream science studies. She finds that, whereas there is congruence in knowledge codes, this is less evident in the case with knower codes. The author 
concludes that the more dispositional aspects of science education have often not been addressed (for example independent learning in science) and that this is a necessary component of epistemic access.

In his 'What is a Gospel? Reflections on Developing an Integrated Literacy Lesson Cycle in a First Year Tertiary Module Using Legitimation Code Theory', Billy Meyer also draws on the tools of LCT to help analyse pedagogical practices in Theology Studies. His particular interest is textual analysis, using the LCT concepts of epistemic semantic density and epistemological condensation. The analysis is further enriched with theorisations from systemic functional linguistics, in particular the work of the Australian linguist J. Martin. The author also works within the pedagogical ambit of David Rose's 'Reading to Learn' approach, and provides a number of tools drawn from these theories/ pedagogies to aid students in unpacking the often dense academic discourses of the university.

In many universities, the National Benchmark Test (NBT) is used as an additional tool (with the Senior Certificate) for placement of students onto the extended curriculum. In her 'Semantic Waves: Writer Performance Ranges on the National Benchmark Tests (NBT) Academic Literacy Test', Naomi Msusa draws on the tools of LCT to examine the nature of the knowledge underpinning the test items, and test-takers' responses to these questions in order to better understand students' preparedness for university study.

In their 'Translanguaging as Foundational Pedagogy: Disrupting Hegemonies for Academic Access in Multilingual Spaces', Sindiso Zhou and Nhlanhla Landa challenge the predominance of a single language of instruction at most universities. Using the theoretical tool of translanguaging the authors propose that a more multilingual approach to learning can support students in gaining access to university knowledge. The authors aim to subvert current language practices and rather utilise the rich tapestry of student linguistic diversity as a pedagogic tool rather than regard it as an impediment to learning.

James Garraway Professional Education Research Unit (PERI)

Fundani Centre for Higher Education Cape Peninsula University of Technology garrawayj@cput.ac.za 
Vivienne Bozalek Director of Teaching and Learning University of the Western Cape vbozalek@gmail.com 